\title{
Effects of Seedling Type on the Establishment, Growth and Precocity of Eastern Black Walnuts (Juglans nigra L.) for Nut Production ${ }^{\S}$
}

\author{
D.K. Brauer ${ }^{*}, 1$, D.E. Brauer ${ }^{2}$, A. Ares ${ }^{3}$, A.L. Thomas ${ }^{4}$, D. Burner ${ }^{2}$ and J. Idassi ${ }^{5}$ \\ ${ }^{I}$ Conservation Production Research Laboratory, ARS-USDA, PO Drawer 10, 2300 Experiment Station Rd., Bushland, \\ TX 79012, USA \\ ${ }^{2}$ Dale Bumpers Small Farms Research Center, ARS-USDA, 6883 South Highway 23, Booneville, AR 72927, USA \\ ${ }^{3}$ Department of Forest Ecosystems and Society, 321 Richardson Hall, Corvallis, OR 97331, USA \\ ${ }^{4}$ Southwest Center, University of Missouri, 14548 Hwy H., Mt. Vernon, MO 65712-9523, USA \\ ${ }^{5}$ North Carolina Agricultural and Technical State University, Cooperative Extension Program, Coltrane Hall, \\ Greensboro, NC 27411, USA
}

\begin{abstract}
Eastern black walnut (Juglans nigra L.) has potential for agroforestry practices in the eastern United States because of its value for nuts and timber; however, practices for optimum nut production are poorly defined. Studies were conducted to determine the type of planting material that can assure successful establishment of black walnut for nut production. The first study compared the survival and growth of bare root and container seedlings. Survival exceeded $95 \%$ with both stock types four years after planting. Bare root seedlings grew less during the first year after planting compared to container stock. No differences in annual growth increment were observed in the next three years. A study was conducted to compare flower production by commercially available open-pollinated seedlings derived from cultivars versus grafted cultivars at three locations in Arkansas and Tennessee. Seventy-two to $87 \%$ of the grafted cultivars flowered during the first four years compared to a maximum of $30 \%$ for the open-pollinated seedlings by the fourth year. A third study verified a previously reported relationship between trunk diameter and nut yields for grafted cultivars. These results suggest that landowners seeking to establish black walnut plantings for nut production should consider using container stock of grafted cultivars selected for improved nut quality.
\end{abstract}

\section{INTRODUCTION}

Changes in the eastern black walnut (Juglans nigra L.) industry in the United States may make orchards or agroforestry practices that include black walnuts grown for nut production more attractive to landowners. Recently, the major American processor of black walnuts initiated a program to buy higher quality nuts at premium prices [1]. High quality nuts are characterized by: 1) high percentage of kernel; and 2) high percentage of the kernel being extracted in large pieces, often referred to halves or quarters. These premium prices should bring the income potential of black walnut nut production to levels similar to that of Midwestern pecan production. Economic analyses by Ares et al. [2] indicated that Midwestern agroforestry practices that produce pecans were profitable. Therefore, economic attractiveness of similar practices utilizing black walnut may increase interest among land owners to establish such plantings.

Address correspondence to this author at the Conservation Production Research Laboratory, ARS-USDA, PO Drawer 10, 2300 Experiment Station Rd., Bushland, TX 79012, USA; Tel: 806-356-5769;

E-mail: david.brauer@ars.usda.gov

${ }^{\S}$ Mentioning of a specific brand does not constitute endorsement by USDA over similar brands and products.
Choices in seedling trees for establishment of black walnut plantings include bare root and container-grown stock. Bare root seedlings tend to be less expensive. Typically, bare root trees are sold for less than \$US 0.50, whereas the cost of container stock usually exceeds \$US 5.00 per tree [3]. However, land owners seem to prefer container stock for orchard establishment (personal observation). Data are lacking on direct comparisons on tree survival and growth between bare root and container stock for establishing black walnut orchards.

The genetics of seedling trees also differ. Native seedlings are from trees that have not been selected for any characteristics. Cultivars of eastern black walnut have been developed by selecting for specific traits related to either timber or nut production. Open-pollinated seedlings derived from such cultivars are from a maternal source of a specific cultivar but the source of the pollen is unknown. Black walnut cultivars are propagated asexually by grafting onto seedling rootstocks.

Native trees and open-pollinated seedlings are often available as either bare root or container stock, whereas the majority of grafted trees are available only as container stock. In most instances, native trees are not planted for nut orchards because they tend to have nuts inconsistently and of poor quality [4]. Numerous cultivars selected for improved nut quality are available [5-8]. When nut sales are the major 
income source, profitability of a black walnut orchard or agroforestry practice should be greater when the juvenile stage of the trees is brief. Estimates of the length of the juvenile stage in black walnuts vary considerably from five to 30 years $[9,10]$. Grafting is a well-established practice to reduce or eliminate the juvenile phase of woody plants [11]. There is some indirect evidence that grafting of scions from mature trees can lead to early flowering and nut production in Juglans species. Nut production by grafted cultivars of black walnuts was observed two to four years after planting $[12,13]$. Grafted seedling trees of English or common walnut (Juglans regia L.) produced flowers the first year after grafting [14]. McNeil and Savage [15] reported a third of grafted $J$. regia scions had nuts four years after grafting while all grafted trees produced nuts during the fifth year. Five-year-old seedling trees of Northern California walnut (Juglans hindsii Jeps.) grafted onto rootstock of $J$. regia produced twice as many nuts as non-grafted $J$. hindsii seedling trees [16]. However, precocious flowering and nut set of non-grafted walnut stock has been reported for certain genotypes of $J$. regia from eastern Europe [17]. There are few reports, if any, in which the flowering of open-pollinated and grafted $J$. nigra cultivars are compared.

Recently, it was reported that at similar trunk diameters native black walnut trees did not yield as many nuts as grafted cultivars [13]. Such results may be related to the length of the juvenile phase in native trees. There was a strong correlation between two-year mean nut yields and trunk diameter for the grafted cultivars [13]. This relationship needs further verification before being applied to economic analyses of nut production by eastern black walnuts. The objectives of these studies were to: 1) compare tree survival and growth of open-pollinated cultivar seedlings established as either bare root or container stock; 2) compare the early production of flowers by openpollinated and grafted cultivars; and 3) verify the previously reported relationship between trunk diameter and nut yields for grafted cultivars.

\section{MATERIALS AND METHODS}

\section{Comparison of Bare Root and Container Stock}

This experiment was conducted near Booneville, Arkansas, USA (N35.095 W93.966). The soil at the site is a Spadra silt loam and black walnut is a recommended tree species for this soil [18]. One-year-old bare root and container (10-L) seedlings of open-pollinated eastern black walnut cultivar (Kwik Krop) were obtained from Forrest Keeling Nursery ${ }^{1}$ (Elsberry, MO, USA). Production method for these seedling trees are described on the company's site [3]. All trees were planted in January 2003 . Holes $(30 \mathrm{~cm}$ in diameter and $60 \mathrm{~cm}$ deep) were dug $3.7 \mathrm{~m}$ apart with an auger a few days before tree planting in rows $7.3 \mathrm{~m}$ apart. Trees were placed in the holes and holes were filled with evacuated soil. Competing vegetation within $1 \mathrm{~m}$ radius of each tree's trunk was controlled by three applications of glyphosate annually (May, mid-June and early August). A slow release fertilizer (14-14-14) was applied at a rate of 60 $\mathrm{g}$ tree $^{-1}$ twice each year (early May and mid-July). During the winter, trees were pruned to promote a single leader. Tree height was recorded at planting and in October annually. The experimental design was a completely randomized block design with two treatments and four replications. Each replication included 12 to 16 trees. Analysis of variance was performed using PROC MIXED of SAS [19] using years as a repeated measure.

\section{Comparison of Flower Production, Tree Growth and Nut Production by Open-Pollinated Versus Grafted Cultivars}

Three experiments were conducted at different sites between 2003 and 2007 in which the flowering of grafted and open-pollinated cultivars were compared. A brief description of the sites and plantation characteristics for the three experiments (Sites 1-3) appears in Table 1. Site 3 is adjacent to the stand in which bare root and container stock types were compared. Both grafted and open-pollinated seedling trees were purchased as container stock (10-L) from Forrest Keeling Nursery ${ }^{1}$ and were produced by their patented $R P M \circledast$ method [3]. Open-pollinated cultivars were one year-old seedlings. Grafted trees had two-year-old rootstocks and one-year old scions at transplanting. Rootstock for the grafted trees at Sites 1 and 2 were from Kwik Krop open-pollinated seedlings, and from Thomas seedlings at Site 3. Cultivars at each site are presented in Table 1. Soil series at each site was determined by Web Soil Survey [18] and verified by on-site examinations.

The presence or absence of flowers (male and female) was recorded between May 10 and 30 annually. Data were collected for four years at Sites 1 and 2, and for three years at Site 3 (Table 1). The occurrence of flowers was analyzed assuming that these data were nominal categorical data, i.e., the presence of flowers $=1$ or absence of flowers $=0$. For a tree to receive a score of 1 for the presence of flowers, it had to have at least one flower of either gender. The effects of site, seedling stock type and year on the presence of flowers were statistically analyzed by logistic regression using PROC LOGISTIC of SAS [19]. The two-way interactions among the main effects were also included in the logistic regression model.

Tree height was recorded with a telescopic tape measure at planting and then annually between the middle of September and the end of October. Nuts per tree were counted in September at all three sites annually. The effects

Table 1. Site Information for Studies Comparing Open-Pollinated and Grafted Cultivars. Names of the Cultivars at Each Site are: EK, Emma Kay; KK, Kwik Krop; Sb, Sauber; Sp, Sparrow. Cultivar Name Refers to the Scion of Grafted Trees

\begin{tabular}{|c|c|c|c|c|c|c|}
\hline Site & County, State & Coordinates & Cultivars & Planting Date & Soil Type & Years Data Collected \\
\hline \hline 1 & Shelby, Tennessee & N35.331 W89.836 & Sp, KK & March 2003 & Grenada silt loam & $2003-2006(4)^{1}$ \\
\hline 2 & Logan, Arkansas & N35.096 W93.966 & Sp, KK & February 2004 & Spadra silt loam & $2004-2007(4)$ \\
\hline 3 & Logan, Arkansas & N35.095 W93.966 & EK, KK, Sb & February 2005 & Spadra silt loam & $2005-2007(3)$ \\
\hline
\end{tabular}

In parenthesis is the number of years in which data were collected. 
of year, site, stock type and scion on tree height and nut production were assessed by analysis of variance using PROC GLM of SAS [19]. Data were analyzed as split-plot design with year as main-plot effect, and site, scion genotype and stock type as sub-plot effects. F-values for the split-plot components were determined using the variable by replication interaction as the denominator. The main difference in analysis of variance between tree height and nuts per tree data was that tree height data included an additional year since heights at planting were entered as data for year zero. Least square means and standard errors (SE) were computed with PROC GLM of SAS [19].

Between 2004 and 2008, meteorological data were recorded at 0.5 -h intervals using a weather station (Model 900, Spectrum Technologies, Inc, Plainfield, IL) located within $2.5 \mathrm{~km}$ of Sites 2 and 3. Data included air temperature, relative humidity, solar radiation, average wind speed for $0.5-\mathrm{h}$ interval, and maximum wind speed during the 0.5 -h interval.

\section{Verification of the Relationship Between Trunk Diameter and Nut Yield for Grafted Cultivars}

Tree growth and yields from seven grafted walnut stands were used in this study (Table 2). Data from 2001 and 2002 from Sites \# 14 and \# 17 were included in the previous study [13]. The crown competition factor, as calculated by the method of Schlesinger [20,21], was less than 100 for each of the seven stands. Such values are indicative of trees growing in open canopy or free-to-grow stage. Rootstocks of the trees at all seven stands were open-pollinated seedlings of the cultivar Kwik Krop. A mixture of scion cultivars was used to graft the trees at each site and these cultivars were the same as in Brauer et al. [13]. Data were collected in September 2005 and 2006. Diameter at breast height (DBH), $1.37 \mathrm{~m}$ above ground, was measured with a diameter tape. Trunk cross-sectional area (TCSA) was calculated from DBH measurements, assuming the trunk's cross section was circular. All the nuts on a tree were counted. Repetitive counts of nuts on trees with several hundred nuts were within $2 \%$ of each other. Nut yields were calculated from nut counts. Number of nuts was converted to air-dry nut mass by using an average nut unit mass reported previously for the studied cultivars $[5,8]$. Stand yield means were determined from data collected from individual trees. Nut yield $(\mathrm{kg}$ of hulled dry nuts tree ${ }^{-1}$ ) and TCSA data from the two consecutive years were averaged. Regression analyses were performed with stand means using PROC GLM of SAS [19].

\section{RESULTS}

\section{Comparison of Bare Root and Container Stock}

Both bare root and container seedling trees had high rates of survival. By the end of the fourth growing season, over $95 \%$ of the seedling trees remained, and there was no difference in survival between bare root and container seedlings (data not shown). At planting, container seedlings averaged over $1 \mathrm{~m}$ in height, whereas bare root trees were approximately $0.5 \mathrm{~m}$ tall (Fig. 1). During the first growing season, there was a small but significant $(P<0.05)$ increase in tree height with container trees (i.e., the comparison of tree height at the end of the first growing season to that at planting). No significant increases in tree height were observed during the first growing season with bare root trees. The annual increase in tree height of bare root seedlings was not less than that of the container stock in the second, third and fourth growing season. Regression equations were computed for tree height as a function of growing seasons for seasons one to four. The slopes of the regression equation were $0.97 \pm 0.03(\mathrm{SE})$ and $0.79 \pm 0.04(\mathrm{SE}) \mathrm{m} \mathrm{year}^{-1}$ for bare root and container seedlings, respectively. These slopes indicate that the annual growth increment during the second, third and fourth growing seasons were not less with bare root seedling trees compared to container stock.

\section{Comparison of Flower Production, Tree Growth and Nut Prpoduction by Open-Pollinated Versus Grafted Cultivars}

Logistic regression indicated that the presence of flowers among open-pollinated and grafted cultivars of black walnuts was significantly affected by stock type (openpollinated versus grafted), but not significantly $(P>0.05)$ by sites and years. The Wald Chi-square for the effects of stock type (degrees of freedom, $\mathrm{DF}=1)$ was $81.4(\mathrm{P}<0.001)$. None of the two-way interactions among main effects were significant at $\mathrm{P}=0.05$. The mean annual percentage of grafted trees with flowers varied between 72 and $87 \%$, when averaged across the three sites (Fig. 2). The annual mean for the percentage of non-grafted trees with flowers was $1 \%$ in the first two years after planting, and increased to $7 \%$ in the

Table 2. Geographical Location and Tree Characteristics of the Seven Stands of Black Walnut Cultivars Used to Verify the Yield Predictive Equation. Mean Trunk Cross-Sectional Area (TCSA) was Calculated from the DBH Measurements Collected on Individual Trees at Each Site in 2005 and 2006

\begin{tabular}{|c|c|c|c|c|c|}
\hline \multirow{2}{*}{ Site Number } & \multirow{2}{*}{ County, State } & \multicolumn{2}{|c|}{ Location's Coordinates } & \multirow{2}{*}{ Tree Age in 2005 (yrs) } & \multirow{2}{*}{ Mean TCSA (cm $\left.{ }^{2}\right)$} \\
\cline { 3 - 5 } & & Latitude & Longitude & 3 & 11 \\
\hline \hline 11 & Shelby, Tennessee & N35.329 & W89.834 & 3 & 12 \\
\hline 12 & Logan, Arkansas & N35.098 & W93.946 & 4 & 25 \\
\hline 13 & Robertson, Tennessee & N36.466 & W86.839 & W & 134 \\
\hline 14 & Logan, Arkansas & N35.101 & W93.935 & 12 & 152 \\
\hline 15 & Logan, Arkansas & N35.098 & W93.946 & 14 & 18 \\
\hline 17 & Cherokee, Kansas & N37.024 & W95.049 & W & 272 \\
\hline
\end{tabular}




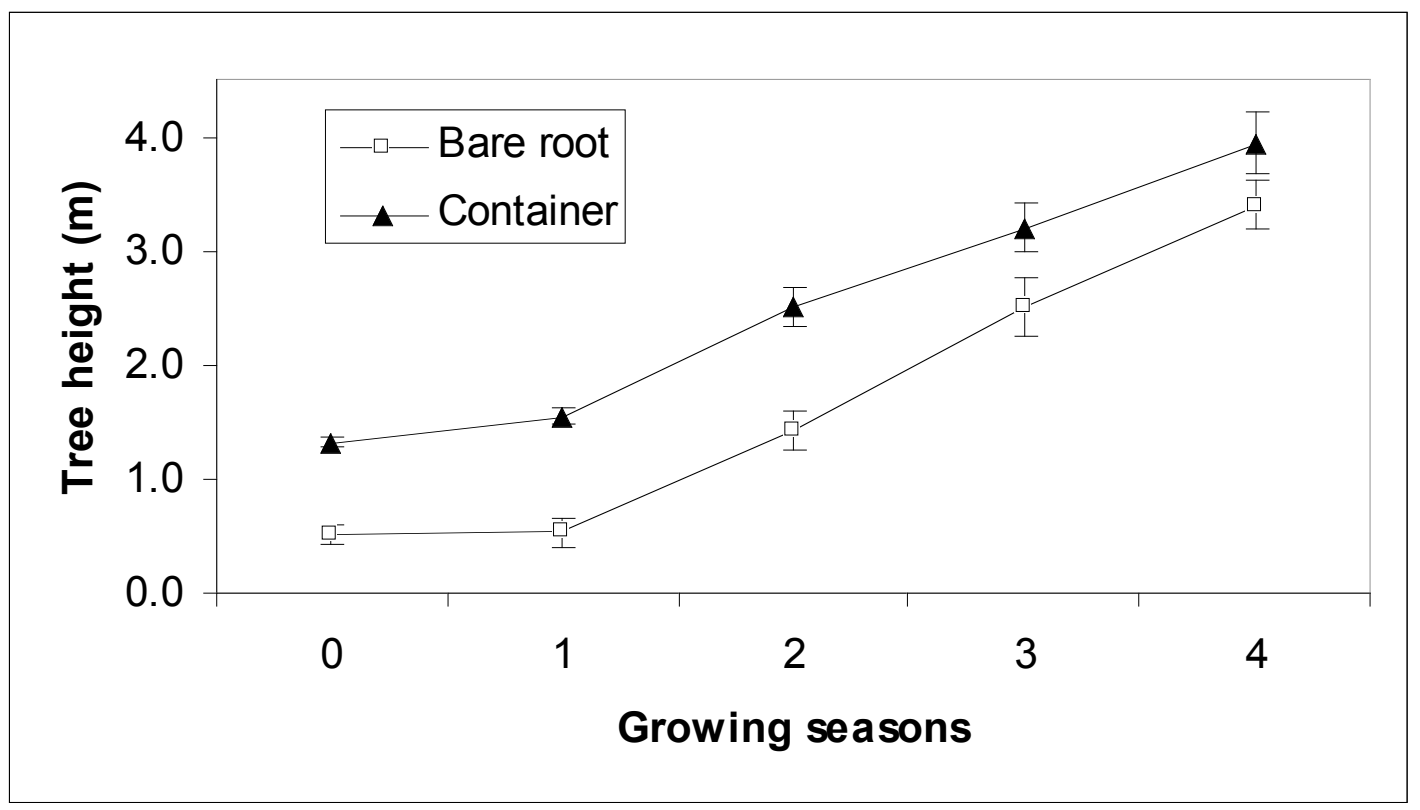

Fig. (1). Tree height of eastern black walnut as affected by seedling stock type and years after planting. Container or bare root openpollinated seedlings from the cultivar Kwik Krop were planted in 2003. Tree height was determined at planting and then at the end of the growing season for four years. Data are means across replications $\pm \mathrm{SE}$.

third year and to $30 \%$ in year four. However, there are indications that open-pollinated seedlings derived from cultivars produced flowers sooner than native trees. Native trees and grafted cultivars were planted in 2003 adjacent to Site 3. During the first four years after planting, none of the native trees flowered (data not shown). In 2009, seven years after planting, $52.6 \%$ of the native trees had flowers, compared to $87.8 \%$ of the open-pollinated seedlings from cultivars.
Tree height was significantly affected by year, but not by stock type, scion genotype or site (Table 3). Tree height was also significantly affected by the two-way interactions of year and site, site and scion genotype, scion genotype and stock type, and year and stock type, and by the three-way interaction among site, scion and stock type. Difference in tree height between grafted and open-pollinated stock types was not significant through the course of the experiment (Fig. 3).

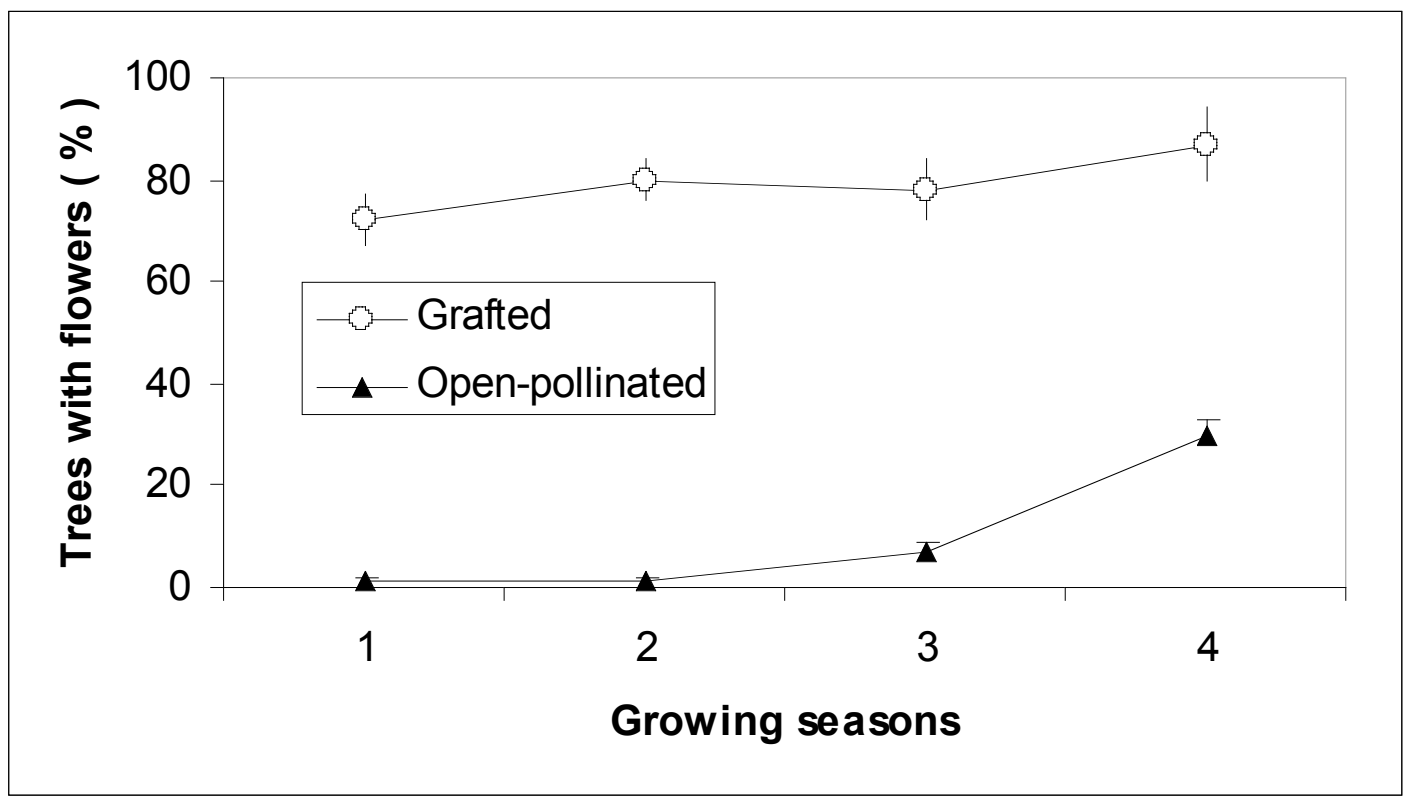

Fig. (2). Flowering of young eastern black walnut trees as affected by growing seasons after planting and seedling stock type, i.e. openpollinated versus grafted cultivars. Presence or absence of flowers was observed in May annually at three sites. Data are means across three sites from at least two cultivars \pm SE. 
Table 3. Summary of the Analysis of Variances of the Effects of Year, Site, Scion Genotype and Seedling Stock Type (OpenPollinated Versus Grafted) on Tree Height and Nuts Per Tree

\begin{tabular}{|c|c|c|c|c|c|c|}
\hline Source of Error & \multicolumn{3}{|c|}{ Tree Height } & \multicolumn{3}{|c|}{ Nuts Tree $^{-1}$} \\
\hline Year*Rep & 30 & 0.025 & & 30 & 0.403 & \\
\hline Site & 2 & 0.122 & 2.10 & 2 & 1.759 & $4.26^{*}$ \\
\hline Scion & 3 & 0.029 & 0.89 & 3 & 0.562 & 0.73 \\
\hline Scion*Rep & 25 & 0.033 & & 25 & 1.048 & \\
\hline Year*Site & 3 & 0.841 & $45.47 * *$ & 1 & 0.061 & 0.21 \\
\hline Year*Site*Rep & 24 & 0.018 & & 8 & 0.283 & \\
\hline Scion*Stock Type & 3 & 2.537 & $47.72 * * *$ & 3 & 0.816 & 1.03 \\
\hline Site*Stock Type & 2 & 0.074 & 1.39 & 2 & 2.217 & 2.70 \\
\hline Year*Stock Type & 3 & 0.179 & $3.37^{*}$ & 2 & 0.492 & 0.62 \\
\hline Site*Scion*Stock Type & 1 & 0.313 & $5.89 *$ & 1 & 0.966 & 1.22 \\
\hline Residual Error & 219 & 0.053 & & 136 & 0.789 & \\
\hline
\end{tabular}

$*, * *, * * *$ indicates the $\mathrm{F}$-value was significant at $\mathrm{P}<0.05,0.01$ and 0.001 level of probability, respectively.

${ }^{1}$ Abbreviations: DF, degrees of freedom; MSS, mean sum of squares.

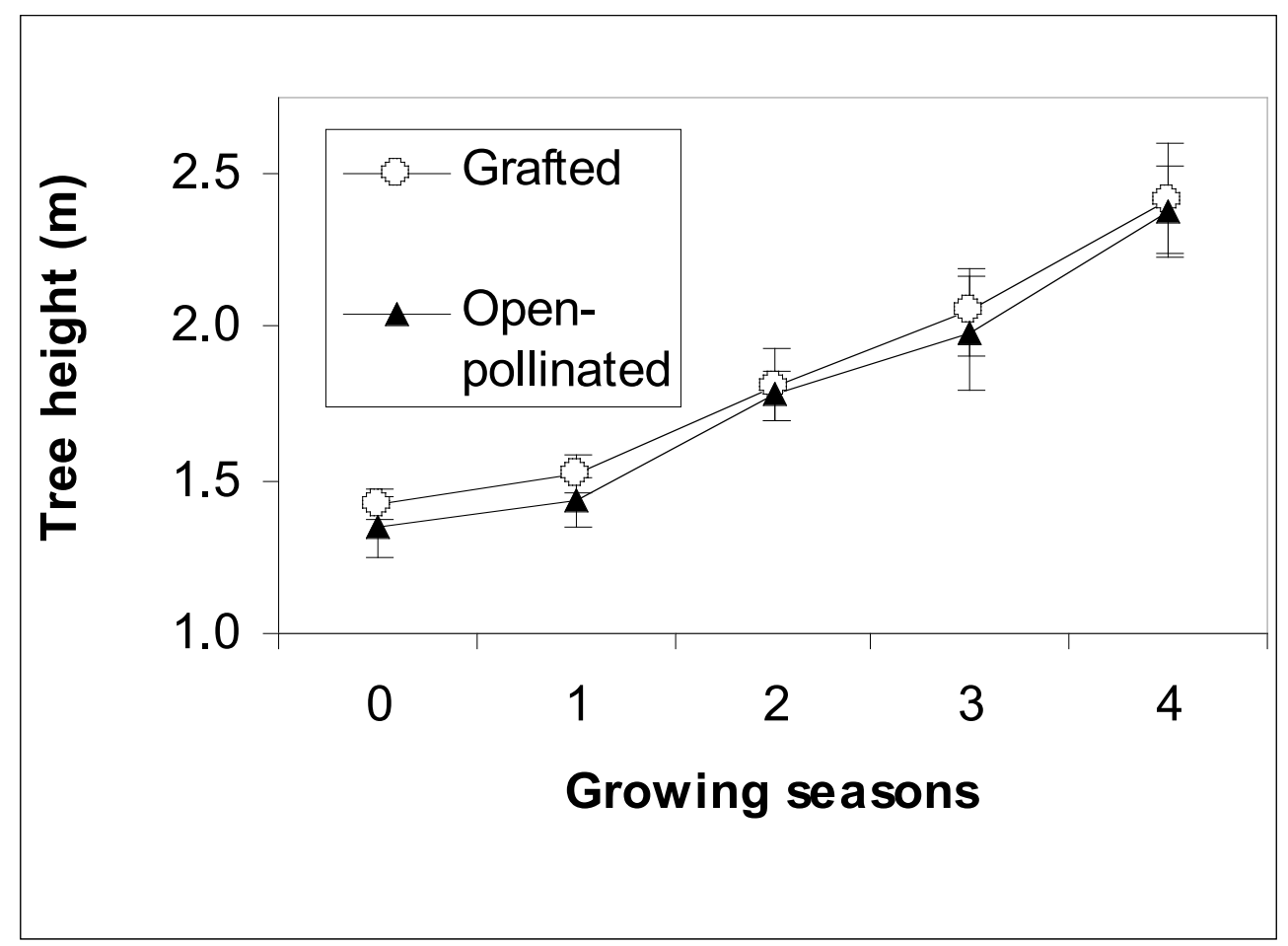

Fig. (3). Tree height of eastern black walnut seedling trees as affected by growing seasons after planting and seedling stock type, i.e. openpollinated versus grafted cultivars. Tree height was measured at planting and then annually in October at three sites. Data are means across three sites from at least two cultivars $\pm \mathrm{SE}$. 
Site, stock type and the two-way interaction between site and scion genotype significantly affected nuts tree ${ }^{-1}$ (Table 3). Grafted trees had higher three-year means for nuts tree ${ }^{-1}$ compared to open-pollinated trees, $0.56 \pm 0.11$ versus no nuts tree ${ }^{-1}$. Trees at Sites 1 and 3 had higher three-year means for nuts tree ${ }^{-1}$, than trees at Site 2, $0.31 \pm 0.08$ and $0.52 \pm 0.19$ nuts tree ${ }^{-1}$ compared to $0.06 \pm 0.04$ nuts tre $e^{-1}$, respectively. The significant $(\mathrm{P}<0.05)$ site by scion interaction probably reflected the inconsistent nut bearing of Kwik Krop scions across the three sites. Three-year means for nuts tree ${ }^{-1}$ was significantly less with Kwik Krop at Sites 1 and 3 compared to other scions, but not significantly different at Site 2. Quality characteristics of nuts were not determined in this study because of the small number of nuts produced.

The 2008 growing season was the first growing season that significant number of nuts had set on the grafted trees at Sites 2 and 3, and few if any nuts on open-pollinated seedlings from cultivars. During June of 2008 there were two straight-line wind events at Sites 2 and 3 in which the wind velocity exceeded $40 \mathrm{~m} \mathrm{~s}^{-1}$. During both of these events the wind was from a northerly direction. The trees at Site 2 are protected from a northern wind by mature trees $(>20 \mathrm{~m}$ in height) adjacent to the location, whereas there is no obstruction north of the trees at Site 3 for over $2 \mathrm{~km}$. At Site 2 , trunks of approximately $20 \%$ of the grafted trees were either broken or severely bent by these two wind events, whereas none of the trunks of the open-pollinated cultivars were damaged. The damage at Site 3 was greater. All $(100 \%)$ of the trunks of the grafted trees at Site 3 were either broken or severely bent, whereas approximately $20 \%$ of the trunks of the open-pollinated cultivars were also damaged by wind at Site 3. None of the trunk damage occurred at the graft union. The grafted trees used in these studies were carefully inspected at the time of planting; trees with any scarring or visual defects were not planted. There were insufficient differences in trunk damage among cultivars and scion-rootstock combinations to make meaningful comparisons that could identify cultivars with greater resistance to such damage. The only characteristic that seemed to be related to the extent of damage was: more trunk breakage occurred in those trees with greater nut loads (data not shown).

High wind velocities are rare at Sites 2 and 3. The weather station recorded only three wind gusts in excess of $40 \mathrm{~m} \mathrm{~s}^{-1}$ from 2004 to 2008 . This represented a frequency of only $0.003 \%$ of the observations during this time period. Wind gusts between 30 and $40 \mathrm{~m} \mathrm{~s}^{-1}$ and 20 and $30 \mathrm{~m} \mathrm{~s}^{-1}$ occurred only $0.059 \%$ and $0.315 \%$ of the time, respectively, during the 2004-2008 time period.

\section{Verification of the Relationship Between Trunk Diameter and Nut Yield for Grafted Cultivars}

The two-year yield means for the seven stands of grafted walnuts increased as TCSA increased (Fig. 4). Data from stands measured in 2005 and 2006 fell within the general variations in yields observed in the previous study [13] for stands with mean TCSA of less than $400 \mathrm{~cm}^{2}$. An equation to predict two-year yield means as a function of two-year mean TCSA was calculated using PROC GLM of SAS [19]:

\section{Two-Year Mean Yield $\left(\mathrm{kg}\right.$ Tree $\left.^{-1}\right)=0.021 *($ Two-Year Mean} $\left.\operatorname{TCSA}, \mathrm{cm}^{2}\right)+0.52$

The R-square for the equation was 0.79 and F-value was $41.8(\mathrm{P}<0.001)$. The $\mathrm{t}$-values for the intercept and slope were $0.9(\mathrm{P}<0.39)$ and $6.5(\mathrm{P}<0.001)$, respectively. Thus, the intercept was not significantly different from zero, but the slope was.

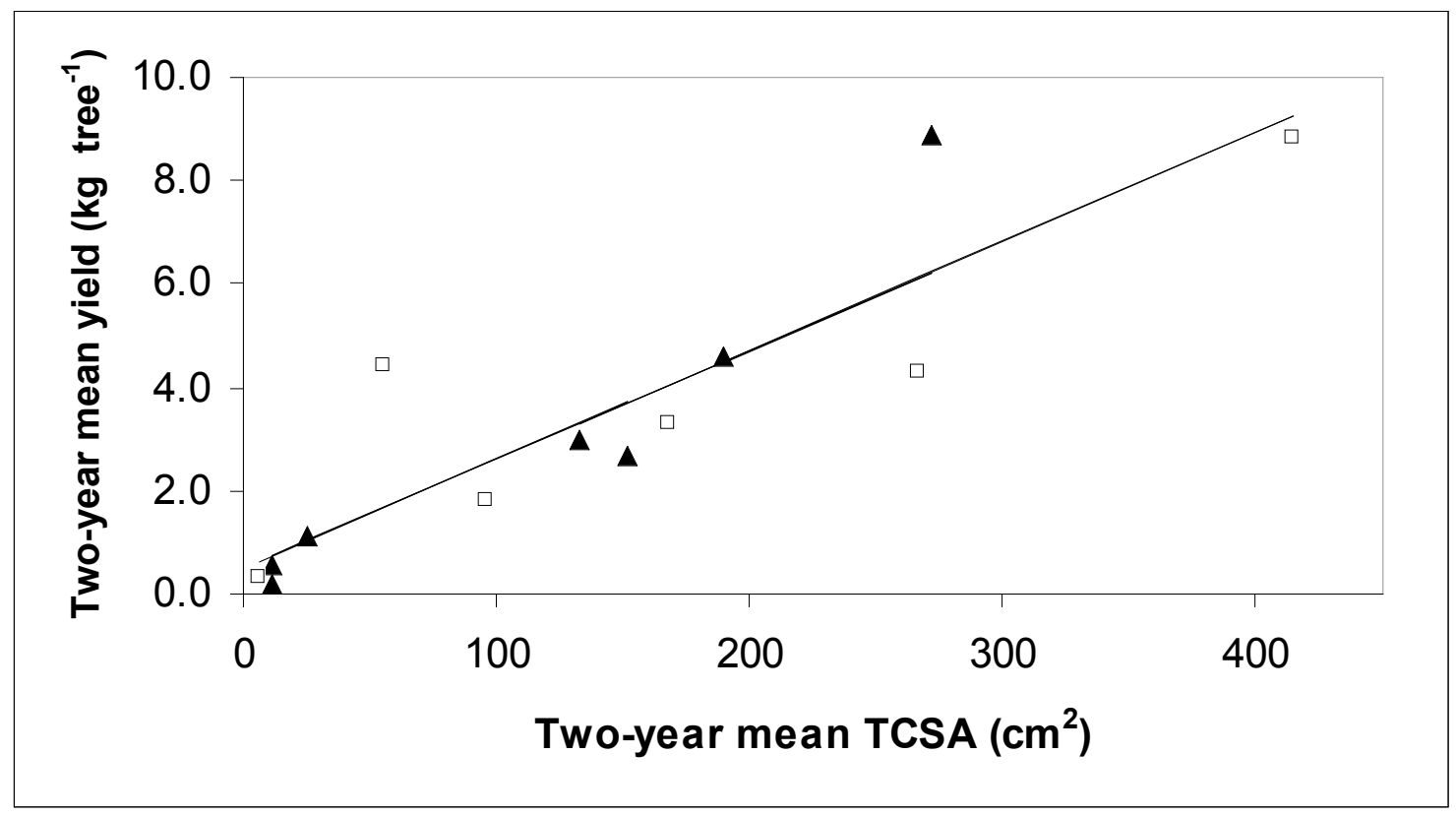

Fig. (4). Relationship between two-year means for nut yields $\left(\mathrm{kg} \operatorname{tree}^{-1}\right)$ and two-year mean trunk cross sectional area $\left(\mathrm{TCSA}, \mathrm{cm}^{2}\right)$. Data collected from the seven stands in 2005 and 2006 are represented by solid triangles. Data represented by open squares were collected from stands of cultivars of black walnuts in 2001 and 2002 and published previously [12]. Predictive equation \#1 is depicted by the solid line. The predictive equation was: Two-year mean yield $=0.021$ (two-year mean TCSA) +0.52 . 


\section{DISCUSSION}

A study reported here directly compared the fitness of the two different stock types, bare root and container, because the planting protocol was the same for both stock types. These results (Fig. 1) indicated that bare root seedlings can be used to established black walnut orchards for nut production. Other results indicate that grafted trees were more likely to flower during the first four years after planting than open-pollinated seedlings derived from the same cultivars (Fig. 2; Table 3). These results indicate that native and open-pollinated trees have a juvenile phase, whereas most of the grafted trees in this study did not. The short or non-existent juvenile phase (precocity) of grafted trees should translate into greater nut production sooner after planting. Planting of grafted trees appears to be the most likely means of achieving a stand with marketable nut yields $\left(>500 \mathrm{~kg} \mathrm{ha}^{-1}\right)$ in less than 10 years.

Data from seven stands of grafted black walnut cultivars indicated that there were a strong correlation between trunk diameter and two-year mean nut yields (Fig. 4). These results are in agreement with earlier research [13]. Most of the economic analyses regarding nut production by eastern black walnuts utilized data from native trees. Previous research [13] has demonstrated that the trunk diameter-nut yield relationship was different for cultivars compared to native trees. Therefore, estimates of nut yields by cultivars in such analyses may be more accurate if the trunk diameter-nut yield relationship from this report is used.

\section{CONCLUSIONS}

Changes in the American black walnut industry, i.e. the major processor buying high quality nuts for a premium price, may make orchards or agroforestry practices that include black walnuts grown for nut production more attractive to landowners. Cultivars of black walnuts selected for higher nut quality will be preferred to either native trees or cultivars selected for timber qualities for plantings in which nut sales are expected to be a significant source of the income. Among black walnut cultivars, there are several options regarding the seedling stock types that landowners can use to establish plantings. We suggest that container stock of grafted cultivars may be a good choice because such seedling trees produce flowers and nuts sooner. A decrease in the time from planting to marketable nut yields should result in a more economically attractively system. The one possible deterrent to the use of grafted container stock is the increased risk of branch and trunk damage from wind when trees are still developing vegetative structures while having large nut loads. The use of bare root stock of open-pollinated cultivars appears to be a viable means of orchard establishment that reduces establishment cost and risk, if landowner can afford to defer income to some point further in the future.

\section{ACKNOWLEDGEMENTS}

Disclaimer: Product names and trademarks are mentioned to report factually on available data; however, the USDA, neither guarantees nor warrants the standard of the product, and the use of the name by USDA does not imply the approval of the product to the exclusion of others that may also be suitable.

ABBREVIATIONS
$\begin{array}{ll}\mathrm{DBH} & =\begin{array}{l}\text { Trunk diameter at breast height, } 1.37 \mathrm{~m} \\ \text { aboveground }\end{array} \\ \mathrm{DF} & =\text { Degrees of freedom } \\ \mathrm{MSS} & =\text { Mean Sums of Squares } \\ \mathrm{TCSA} & =\text { Trunk cross-sectional area } \\ \mathrm{SE} & =\text { Least square standard errors }\end{array}$

\section{REFERENCES}

[1] Hammons B. A vision for the black walnut nut industry: more \$ with better nuts. Annu Rep North Nut Growers Assoc 2001; 92: 57 9.

[2] Ares A, Reid W, Brauer D. Production and economics of native pecan silvopractices in central United States. Agroforestry Syst 2006; 66: 205-15.

[3] Forrest Keeling Nursery. What is RPM $®$ Available at http:/www.fknursery.com/index.cfm/fuseaction/home.showpage/p ageID/18/index.htm, [Verified February 13, 2009].

[4] Garrett HE, Kurtz WB. Silvicultural and economic relationships of integrated forestry-farming with black walnut. Agroforestry Syst $1983 ; 1: 245-56$.

[5] Bish C. Why nut evaluation? In: Jones JE, Mueller R, Van Sambeek JW, Eds. Nut production handbook for eastern black walnut. NRCS/USDA, Republic, MO: Southwest Missouri Resources, Conservation \& Development, Inc 1998; pp. 44-59.

[6] Coggeshall MV. Black walnut improvement program at the University of Missouri. Annu Rep North Nut Growers Assoc 2002; 93: 93-6.

[7] Hanson B. Black walnut cultivar performance project. Annu Rep North Nut Growers Assoc 2003; 94: 120-32.

[8] Reid W, Coggeshall MV, Hunt KL. Black walnut cultivars for nut production. Annu Rep North Nut Growers Assoc 2004; 95: 65-78.

[9] Williams RD. Black Walnut, Juglandaceae-Walnut family. In: Burns RM, Honkala BH, Eds. Silvics of North America. Hardwoods, agriculture handbook 654. US Forest Service/ USDA, Washington DC, USA. 1990; Vol. 2: Available at http://www.na.fs.fed.us/spfo/pubs/silvics_manual/table_of_content s.htm, [Verified February 13, 2009].

[10] Woodroof JG. Black walnuts. In: Tree nuts: production, processing, products, $2^{\text {nd }}$ ed. Westport CT, USA: AVI Publishing Company, Inc. 1982; pp. 604-615.

[11] Hackett WP. Juvenility, maturation, and rejuvenation in woody plants. Hortic Rev 1985; 7: 147-55.

[12] Brauer D, Jones JE. Results on the establishment of named varieties of eastern black walnuts on an upland site in the Ouachita region of Arkansas. Annu Rep North Nut Growers Assoc 2003; 94:133-45.

[13] Brauer D, Ares A, Thomas A. Cultivars of eastern black walnut (Juglans nigra L.) have greater nut yields than native trees at similar trunk cross-sectional areas. J American Pomological Society 2009; 63: 42-50.

[14] Bota M, Godeanu I, Baciu A. The behavior of some walnut cultivars and selections in the first year after planting. Acta Hortic 2001; 544: 141-6.

[15] McNeil DL, Savage GP. New Zealand walnut variety trials 1985 1999. Acta Hortic 2001; 544: 157-61.

[16] Reil WO. Comparison of Chandler walnut grown on both Paradox and northern California black rootstock that were planted as seed, seedling or grafted trees. Acta Hortic 2001; 544: 481-8.

[17] Germain E, Delert F, Kanivets V. Precocious mating walnut populations originating from central Asia: their behavior in France. Acta Hort 1997; 442: 83-8.

[18] NRCS/USDA. Web Soil Survey. Available at: http://websoilsurvey.nrcs.usda.gov/app/WebSoilSurvey.aspx [Verified February 13, 2009].

[19] SAS Institute. SAS/STAT user's guide, version 8. SAS Institute Inc., Cary, USA, 1999; Vol. 2. 
[20] Schlesinger RC. First thinning. In: Burde EL, Ed. Walnut notes. St. Paul, Minn. U.S. Department of Agriculture, U.S. Forest Service, North Central Forest Experiment Station. Note 303. 1988. Available at: http://nrs.fs.fed.us/pubs/1767
[21] Schlesinger RC. The effects of crowding on black walnut tree growth. In: Van Sambeek JW, Ed. Knowledge for the future of black walnut. Proc $5^{\text {th }}$ Black Walnut Symp. General Technical Report NC-191, North Central Forest Station, USFS, St. Paul, Minn., USA 1996; pp. 139-45.

Received: October 17, 2009

(C) Brauer et al.; Licensee Bentham Open.

This is an open access article licensed under the terms of the Creative Commons Attribution Non-Commercial License (http://creativecommons.org/licenses/by$\mathrm{nc} / 3.0 /$ ) which permits unrestricted, non-commercial use, distribution and reproduction in any medium, provided the work is properly cited. 